\title{
THE INDONESIAN TITANIUM DEPOSIT TYPES AND THEIR RESOURCES: THE ASPECTS FOR TITANIUM COMMODITY DEVELOPMENT
}

\author{
by: \\ Armin Tampubolon \\ Pusat Sumber Daya Geologi \\ Jalan Soekarno-Hatta No.444, Bandung
}

\begin{abstract}
Indonesia has several Titanium deposit types: beach placer, alluvial and lateritic types. The source of Titanium minerals in beach placer is derived from Tertiary Volcanic Rocks. The occurence of alluvial Titanium deposit is closely associated with cassiterite (tin minerals) alluvial in Bangka-Belitung Islands. The source of Titanium minerals (ilmenite) are derived from weathering on tin mineralization hosted in metamorphic and granitic rocks within uplifted morphology areas.
\end{abstract}

Lateritic Titanium deposits are formed by lateritization process in association with bauxite and nickel in Riau, Kalimantan and Sulawesi Islands. The sources of Titanium are in granitic and metamorphic basement rocks.

Java beach placer resources are quite big in tonnage, nearly 50 million tons in total, with significant $\mathrm{TiO}_{2}$ contents ranging from $8.91 \%$ to $3.17 \%$. Beach placer along the south shoreline of Java seems to indicate consistency in their mineralogical and genetic types with relatively homogenous in $\mathrm{TiO}_{2}$ contents.

Sumatra shows significant resources for lateritic Titanium deposit that is up to $107,800,859$ tons with $0.5 \%$ to $15 \% \mathrm{TiO}_{2}$. The quite interesting resources are indicated by very significant $\mathrm{TiO}_{2}$ average (15\%) with the total of 19,243,757 tons of lateritic deposit type in Bintan Island, Riau, Sumatra. The total resources of beach placer type deposits in Sumatra are much lower than lateritic ones.

Sulawesi has both beach placer and lateritic types where the interesting resources of this island are indicated by quite big resources and significant values in $\mathrm{TiO}_{2}$ grades in North Sulawesi; the tonnage is up to $31,400,000$ tons with $\mathrm{TiO}_{2}$ content average is $9.85 \%$.

On the basis of resources and processing technologies, beach placer deposits in Sumatera, Java and Sulawesi are thought to have potentially economic significance. However, such available resources are needed to upgrade by performing detailed and systematic exploration. Government policies and environment concerns are important aspects for consideration in Titanium commodity development of this country.

Keyword: beach placer, policy, resources, technology, Titanium.

\section{SARI}

Indonesia memiliki beberapa jenis endapan Titanium: plaser pantai, aluvial dan laterit. Sumber mineral Titanium jenis plaser pantai berasal dari Batuan Gunungapi Tersier. Keterdapatan endapan Titanium aluvial sangat berkaitan dengan kasiterit (mineral timah) aluvial di BangkaBelitung. Sumber mineral Titanium (ilmenit) berasal dari hasil pelapukan mineralisasi timah pada batuan induk metamorf dan granit pada lingkungan morfologi pengangkatan.

Endapan laterit terbentuk melalui proses lateritisasi yang berkaitan dengan bauksit dan nikel di Riau, Kalimantan dan Sulawesi. Sumber Titanium berasal dari batuan dasar metamorf dan granit.

Sumberdaya Titanium plaser pantai di Jawa cukup besar, mendekati 50 juta ton dengan kandungan $\mathrm{TiO}_{2}$ berkisar dari 8,91\% hingga 3,17\%. Plaser pantai sepanjang garis pantai selatan Jawa tampaknya menunjukkan konsistensi dari segi mineralogi dan jenis genesanya dimana cukup merata dalam kandungan $\mathrm{TiO}_{2}$ 
Sumatera memperlihatkan sumber daya yang signifikan untuk endapan Titanium jenis laterit yaitu mencapai 107.800.859 ton dengan kadar $\mathrm{TiO}_{2}$ berkisar 0,5\% hingga 15\%. Sumberdaya yang cukup menarik ditunjukkan di Pulau Bintan dan Riau dengan jumlah 19.243.757 ton jenis laterit dan kandungan $\mathrm{TiO}_{2}$ rata-rata sebesar 15\%. Jumlah sumberdaya endapan jenis plaser pantai di Sumatera jauh lebih rendah dibandingkan sumberdaya laterit.

Sulawesi memiliki jenis laterit dan plaser pantai dengan sumberdaya yang cukup besar dan kandungan $\mathrm{TiO}_{2}$ di Sulawesi Utara cukup signifikan, mencapai 31.400.000 ton dimana kandungan rata-rata $\mathrm{TiO}_{2}$ mencapai $9,85 \%$.

Dengan berdasarkan sumber daya dan teknologi pengolahan, endapan plaser pantai di Sumatera, Jawa dan Sulawesi dinilai berpotensi memiliki nilai ekonomi, namun sumberdaya yang ada tersebut memerlukan peningkatan status melalui penyelidikan rinci, terarah dan sistematis. Kebijakan pemerintah dan kepedulian lingkungan merupakan aspek penting dalam pengembangan komoditas Titanum di Indonesia.

Kata kunci: plaserpantai, kebijakan, sumberdaya, teknologi, Titanium.

\section{INTRODUCTION}

Historically, the first discovery of Titanium-mineral deposits was recorded when the private company had attempted to treat titanferous magnetite minerals of iron sands of beach placer deposits along the south coast of Java Island in 1910 (Van Bemmelen, 1949).

When Chinese came for the first time to develop placer tin mining in Bangka and Belitung Islands during $18^{\text {th }}$ century, it can also be recorded as the initial discovery but there was no evidence of Titanium processing took place at that time. These islands are now recognized as the main tin belt that are closely associated with placer Titanium mineral deposits.

Up to now, as a part of inventory program, Centre for Geological ResourcesGeological Agency (CGR-GA) has conducted a number of projects on Titanium deposits. Data used in this paper mostly compiled from investigation results at CGR. However, from the beneficiation point the Titanium mineral resources in Indonesia has not been optimized yet even though some researches on the use of these minerals for pigment industry have been done by other institutions for some time. Indonesia has some Titanium deposit types: beach placer or alluvial and lateritic types.

This paper deals with Titanium deposit types occurred in Indonesia and the estimated resources for every different deposit type in different localities as compiled particularly from previous exploration activity reports. This also contains the discussion on the likely follow up investigation orfuture development of the available Titanium resources to become Titanium commodity in economic level. There are many aspects that can be considered in evaluation of resources to be economic commodities, However this paper does not include all kind of aspects but only the deposit type and the resources aspects will be emphasized as basic considerations.

\section{TITANIUM DEPOSIT TYPES}

\section{Beach Placer Deposit}

The beach placer deposits show large distribution covering extent coastal areas where mineral type of Titanium is chiefly ofilmenite $\left(\mathrm{FeTiO}_{2}\right)$. Their occurrences are closely related to iron sands (magnetite or titano-magnetite minerals) on the beach. The formation of beach placer Titanium deposits in Indonesia can be explained by considering their relationships with magnetite and other heavy minerals deposited together along shoreline. The illustration of their formation is shown at Figure 1.

The main sources of Titanium mineral sands is in heavy mineral-bearing Tertiary Volcanic Rocks which is largely distributed near the beach in most of main islands like Sumatra, Java and Sulawesi. As the rock source weathered and exposed within the erosional areas of a river which carries its load of sediment into the ocean, the sediments are accumulated in littoral drift or deltaic areas or long shore drift. When the high tide condition happens, tiny size of 


\section{MAKALAH ILMIAH}

particles that seated on the bottom of the sea will come up as caused by under current turbulence works upward. During low tide, the heaviest particles will not be brought by current down award back to the bottom of the sea but they will remain and then deposited on the beach.

Volcanic rock surface in certain area near ocean that has extremely strong wave energy is occasionally eroded directly by wave action and caught up in longshore drift and washed up into beaches where the lighter minerals are windowed. Quotation from some reports on iron sand deposit along the south Java beach indicates that some magnetite minerals is concentrated by waves. This is shown by thin layers on the beach sand profiles (Figure 2).

Heavy mineral sands show variation in thickness, depending on availability of related rock formation near the beach, waves and tidal conditions. The thickness in Sumatera shows various numbers with different grain size where depth interval ranges from $2 \mathrm{~m}$ to $3 \mathrm{~m}$ with fine to medium and coarse grain size distribution containing $8.54 \%-16.19 \% \mathrm{TiO}_{2}$ (Figure 3). From recent investigation, mineral composition in that area consists chiefly of magnetite (up to $62 \%$ ), ilmenite (up to $10,7 \%$ ), quartz and amphibole (Anonim, 2012).

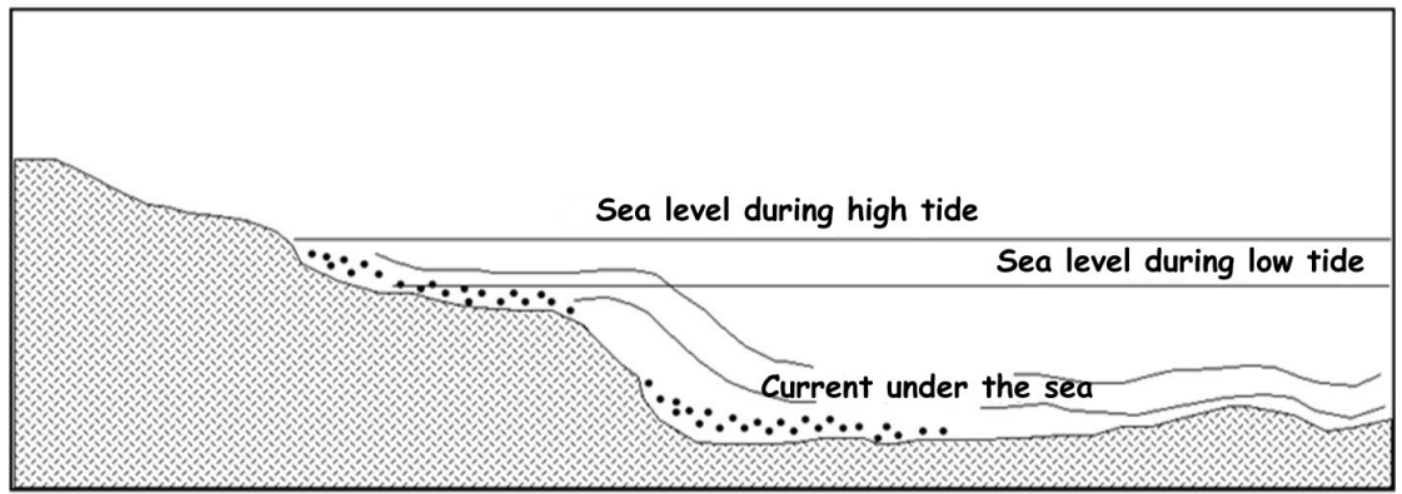

Figure 1. Illustration of beach placer deposition during high-low tide level within the potential coastal areas in Indonesia (Anonim, 2005)

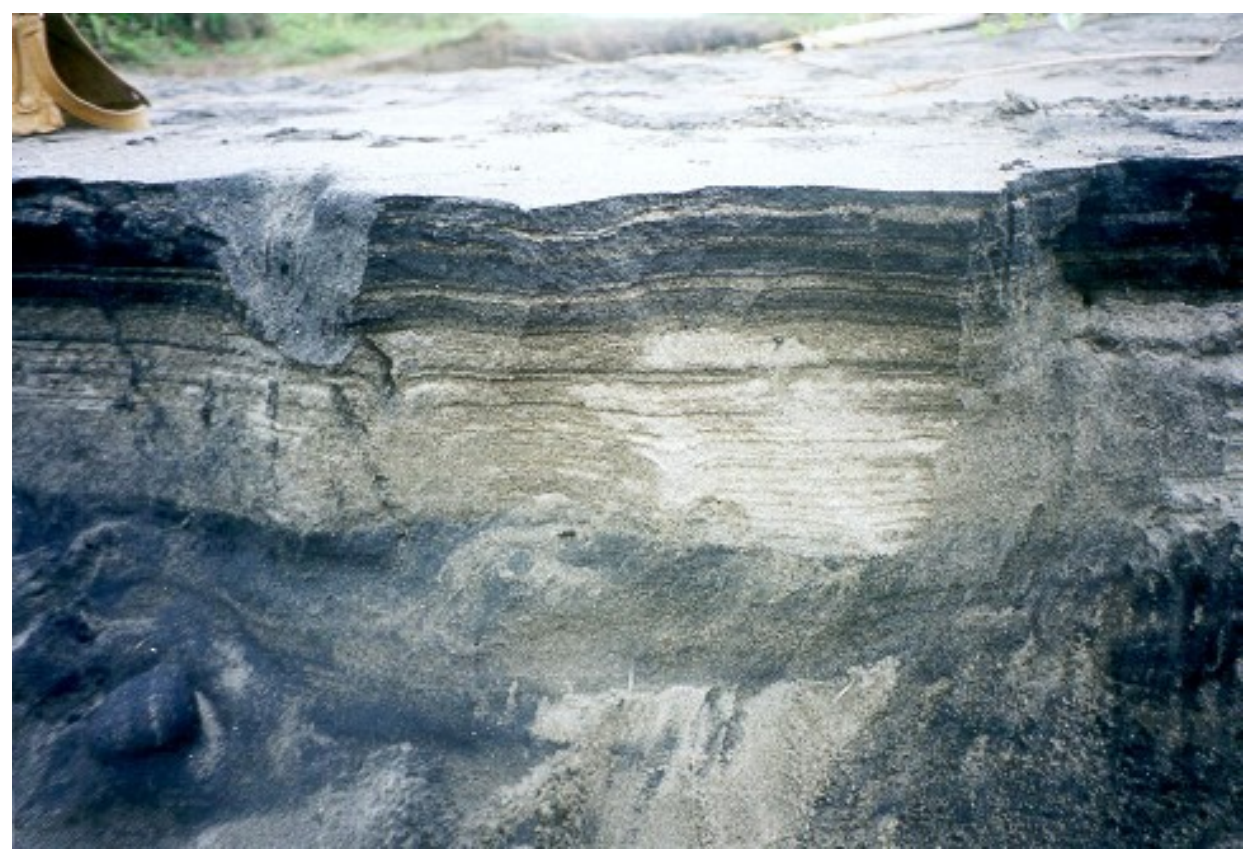

Figure 2. Sand deposits with thin layers of black heavy mineral (iron and Titanium minerals) at South Cianjur Beach, West Java, Indonesia (Anonim, 2005) 


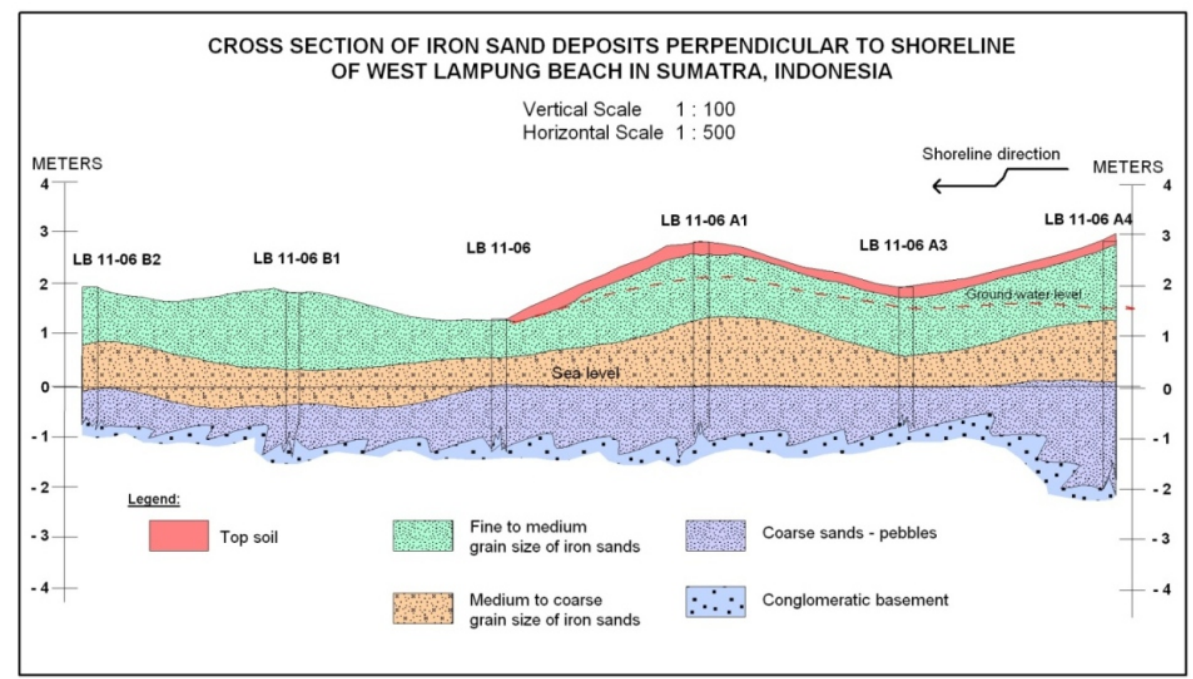

Figure 3. Cross section of iron sand deposits perpendicular to shorelie of West Lampung Beach, Sumatra- Indonesia (Anonim, 2012)

\section{Inland Alluvial Deposit Types}

The occurence of inland alluvial Titanium minerals is closely associated with casiterite (tin minerals) alluvial in BangkaBelitung and Riau Islands. Ilmenite products from these islands had been exploited as by product of tin. Unlike in Java, ilmenite minerals in these islands are considered to be less economic values because there are some more economic mineral associations such as monazite, zircon and xenotime known as main REE (Rare Earth Element) sources. Geological environment of this alluvial deposit is quite different from beach placer along shoreline areas in that composed of Triassic granitic rocks that intruded Carbonaceous metamorphic rocks.

Titanium minerals (ilmenite) as a by product of tin in Bangka-Belitung and Riau Islands occurred together with cassiterite, zircon, monazite, xenotime, rutile.
Sometimes tourmaline minerals are believed to have derived from weathering tin mineralization of vein and greissen or skarns types hosted in metamorphic and granitic rocks of uplifted morphology environment. Rock fragments are transported and depositedin low land in the surrounding areas to form alluvial deposits and even further end up to the nearest sea bed.

The illustration of the sources of heavy minerals within intensive weathering influence and erosion areas of river in Bangka is shown at Figure 4. Various heavy mineral-bearing metamorphic and granitic rocks were eroded on gradual different erosion level and transported and deposited in low land with various mineral grain sizes. Mineralogical types of alluvial deposits in Bangka-Belitung consist mainly of cassiterite, monazite, zircon, rutile, ilmenite, tourmaline, garnet and wolframite.

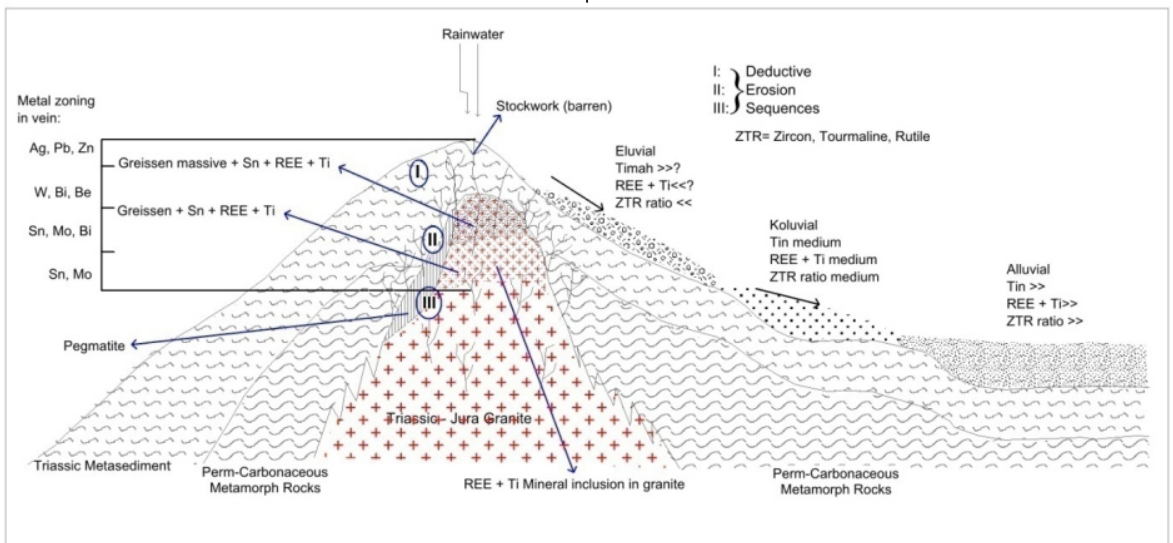

Figure 4. Illustration to show the depositionprocess of Titanium and other heavymineralsources in Bangka-Belitung, Indonesia (PSDG-PT.Timah Tbk, 2013) 


\section{Lateritic Deposit Types}

Indonesian lateritic deposit types are very famous in terms of geological view because there are some commodities that have been long time produced as mining commodities such as nickel and bauxite. However, there are not many references dealing with Titanium minerals in genetic relation to these commodities. The occurence of nickel and bauxite lateritic deposits show typical local geology background. Bauxite occurred in graniticdioritic-gabroic rock environment while nickel is confined to ultrabasic rock units. Lateritization by which bauxite and nickel formed is undoubted as the main process to yield huge bauxite and nickel deposits in Indonesia regions. From chemical analysis results, both bauxite and nickel indicate to have association with other metals as by product including Titanium. The values of Titanium content in nickel laterite seems not significant, mostly less than $1 \%$, some bauxite location in Sumatra show significant $\mathrm{TiO}_{2}$ contents. Unfortunately, there is no available report on mineralogical types of Titanium in lateritic deposits in Indonesia, theoretically this may be a kind of anatase mineral and thus different from two types of Titanium deposits previously mentioned.

\section{TITANIUM RESOURCES}

The estimation of Titanium resources by using hypothetical approach is a part of metallic inventory program periodically and sustainably conducted by Center for Geological Resources (CGR) on the year basis of updating data input. Data references are compiled not only from available data at CGR but also from other institutions and private or state-owned companies.

The Titanium resources of beach placer are indicated to be largely distributed in main islands such as Sumatra, Java and Sulawesi. They are closely related to Tertiary Volcanic Rocks. Sumatra shows significant resources for lateritic Titanium deposit that is up to $107,800,859$ tons with the grade of $\mathrm{TiO}_{2}$ ranging from $0.5 \%$ to $15 \%$. The quite interesting resources are indicated by very significant $\mathrm{TiO}_{2}$ content averaged $15 \%$ with the total of $19,243,757$ tons of lateritic deposit type in Bintan Island (Figure 5). The total resources of beach placer type deposits in Sumatra are much more lower than lateritic ones.

Java Island is known to have more potential Titanium-mineral resources of beach placer types compared to other regions in Indonesia. This island has long history in iron sand mining where ilmenites is also produced as by product of iron sand concentrate but not recorded properly about its production data. In 1972, the recorded total of magnetite and ilmenite produced from Cilacap in Central Java was 300,000 tons with ilmenite contents $>15 \%$. These products were exported to Japan. Up to now, magnetite and ilmenite concentrates under new governmental regulations are still produced from small to medium scale of mines. The resources or even the reserves of this island are quite big, nearly 50 million tons in total, with significant $\mathrm{TiO}_{2}$ content ranging from $8.91 \%$ to $23.17 \%$ (Figure 6 ). Beach placer along the south shoreline of this island seems to indicate consistency in their mineralogical and genetic types with relatively homogenous in $\mathrm{TiO}_{2}$ contents. This deposit type shows typical simple mineralogical composition which are dominantly composed of magnetite, ilmenite and quartz.

The very big volume of lateritic Titanium is shown in Kalimantan Island but the grade content of $\mathrm{TiO}_{2}$ is very low, less than $1 \%$. This is nearly same as primary $\mathrm{TiO}_{2}$ content in fresh igneous rock condition (Figure 7). Flores Island in Nusa Tenggara Province shows small quantity of Titaniummineral resources with $\mathrm{TiO}_{2}$ content averaged of $7.15 \%$.

Sulawesi has two types of Titaniumrelated deposits i.e. beach placer and lateritic types (Figure 8). Like in Kalimantan, lateritic deposit types of Sulawesi show very big in volume but very low in $\mathrm{TiO}_{2}$ contents. Even though they are different in lithological units but they have undergone same lateritisation process to form lateritic Titanium deposits in both Kalimantan and Sulawesi islands and they have similarity in $\mathrm{TiO}_{2}$ contents. This fact implies that laterisation intensity may be dominant factor influencing deposit quality. Conversely, the quality and quantity of Bintan lateritic deposits are relatively better compared to that of Kalimantan and Sulawesi ones. 


\section{MAKALAH ILMIAH}

The interesting resources of Sulawesi are indicated by both quite big resources and significant values in $\mathrm{TiO}_{2}$ grades encountered in North Sulawesi with the tonnage is up to $31,400,000$ tons and $\mathrm{TiO}_{2}$ content average is $9.85 \%$.

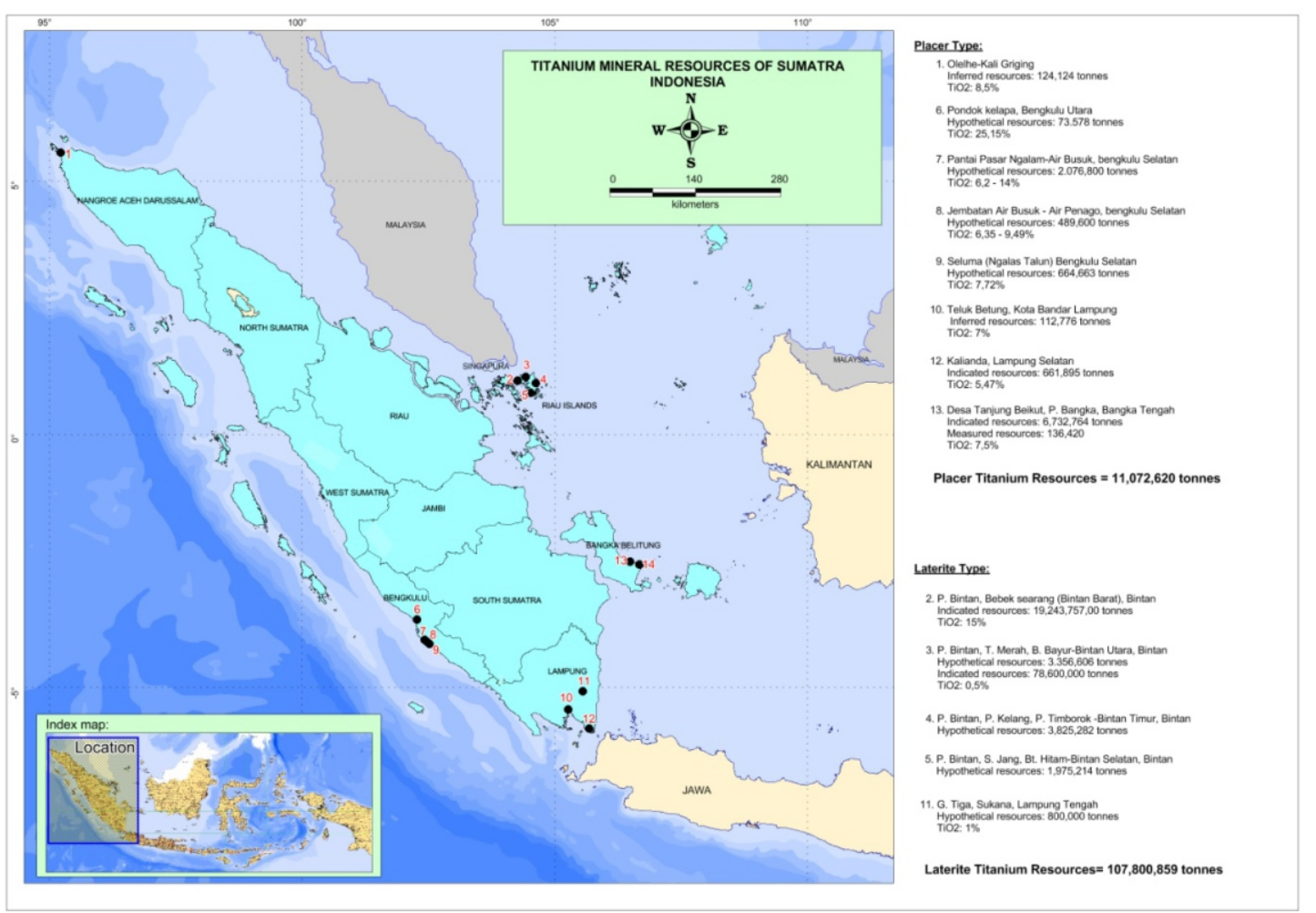

Figure 5. Titanium mineral resources of Sumatera, Indonesia

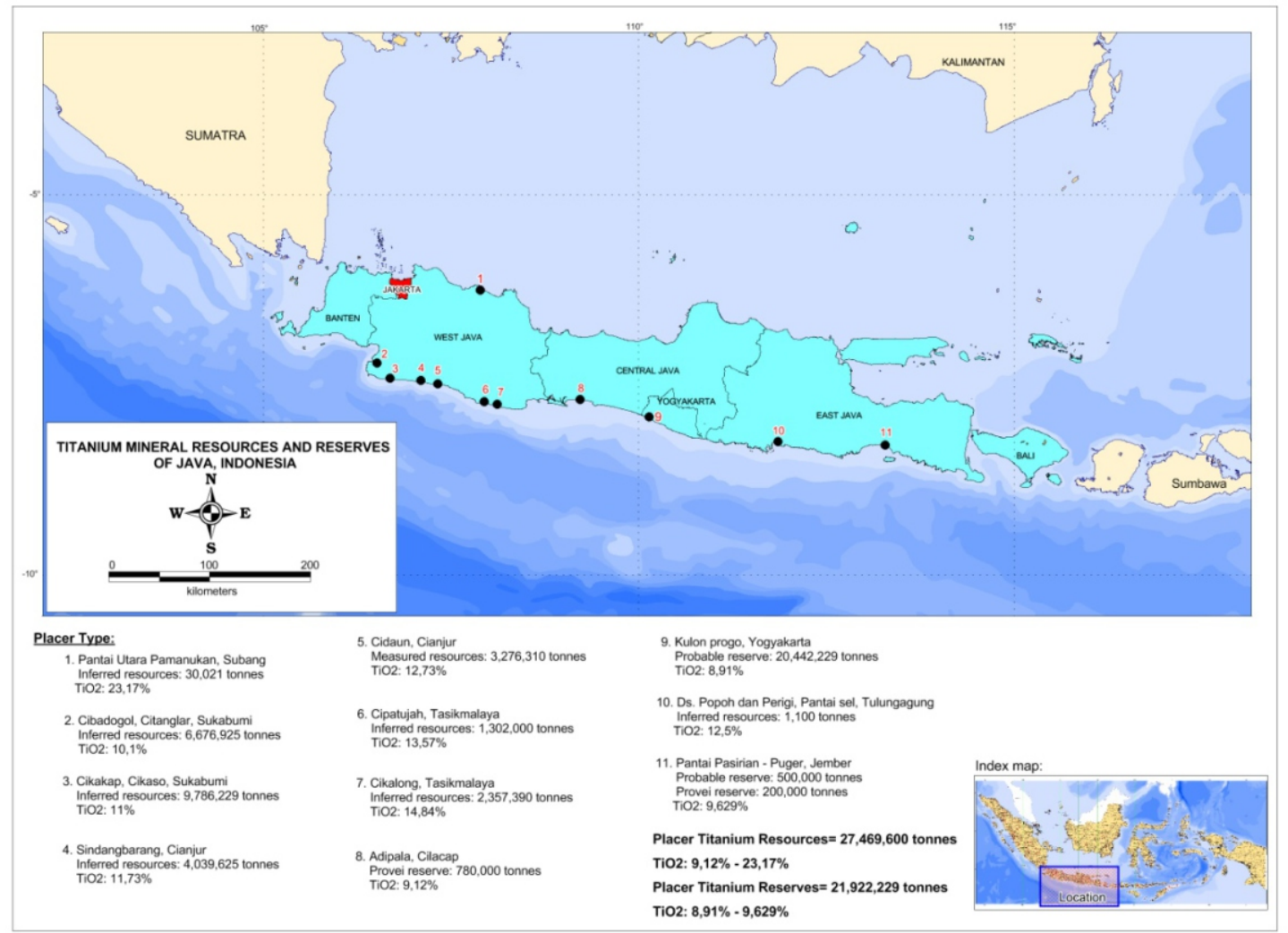

Figure 6. Titanium mineral resources of Java, Indonesia 


\section{MAKALAH ILMIAH}

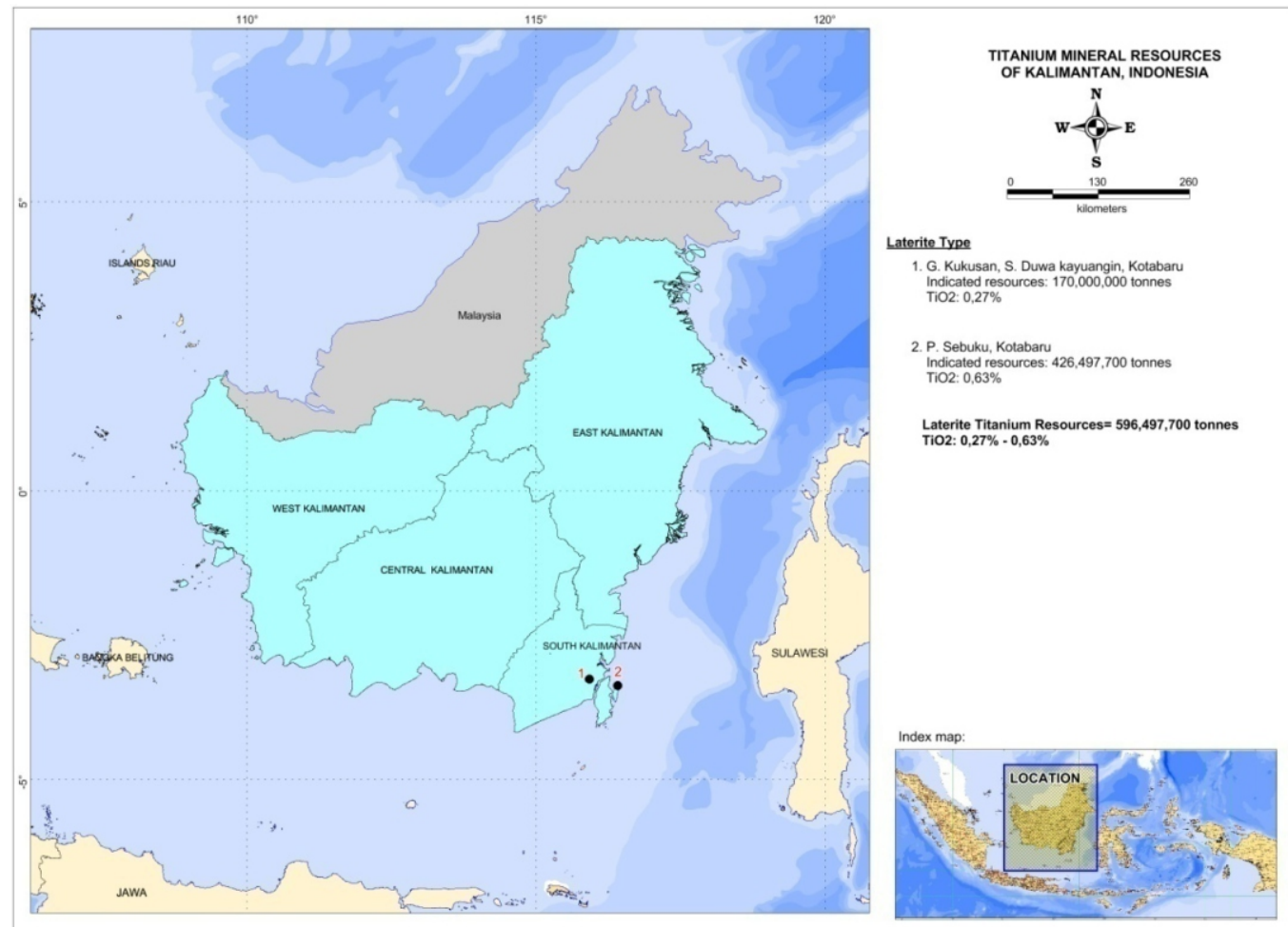

Figure 7. Titanium mineral resources of Kalimantan, Indonesia

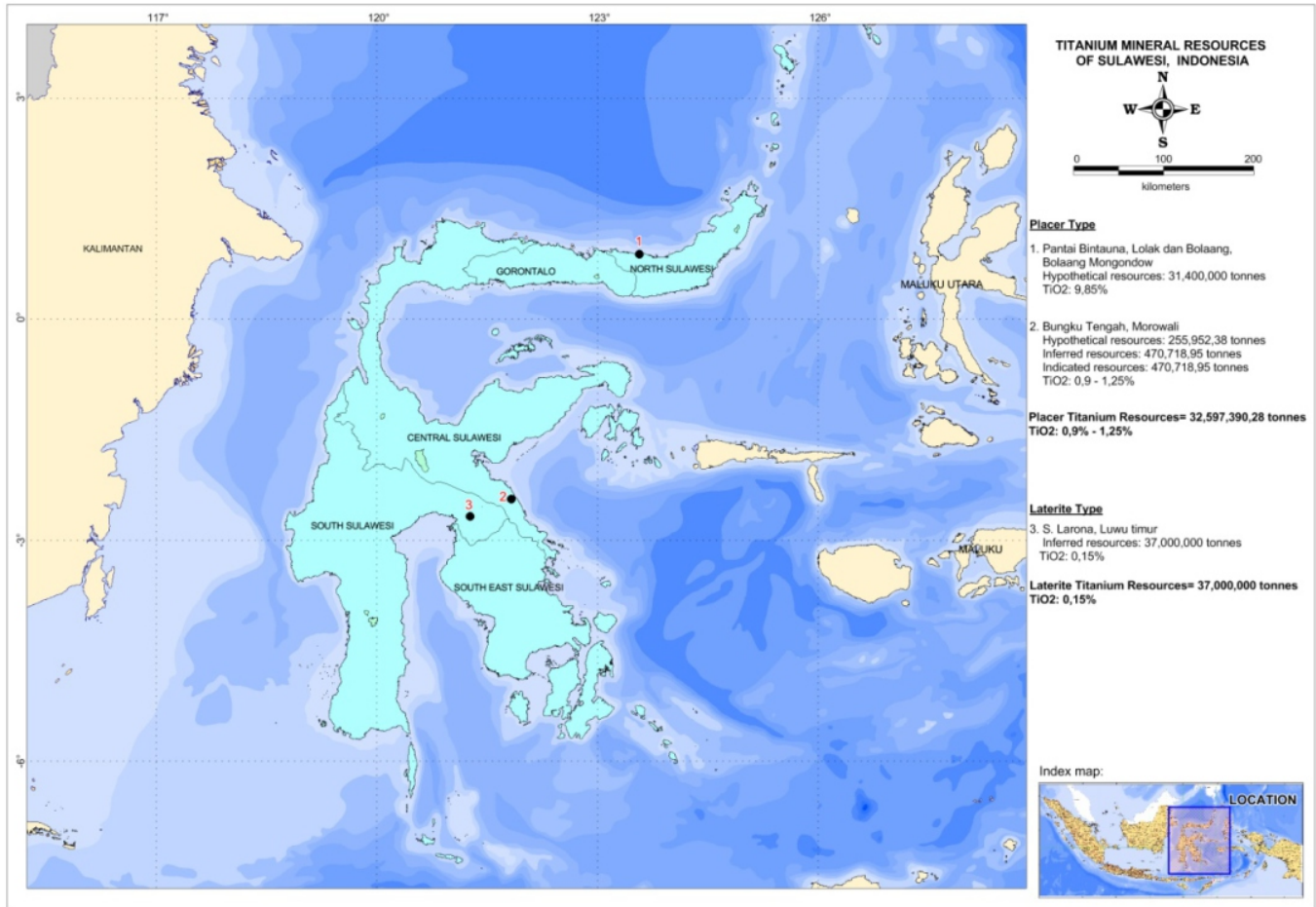

Figure 8. Titanium mineral resources of Sulawesi, Indonesia

Beach placer deposits near to Tertary Volcanic Rock regions such as Sumatra, Java, Flores and Sulawesi Islands are composed mainly of the following heavy minerals: magnetite, pyroxene, quartz, hematite and ilmenite. In Bangka-Belitung Islands, mineral compositions of placer deposits are composed generally of cassiterite, monazite, rutile, zircon, ilmenite, tourmaline, epidote, garnet and quartz. 


\section{DISCUSSION}

There are many aspects to be considered for beneficiation development, however we can only analysis onquantity, deposit types and $\mathrm{TiO}_{2}$ content point of views. Referring to data compilation on economic significance of deposit examples collected from different countries in Table 1, it can be seen that placer deposits have present great importance. With comparison to this table, Indonesian Titanium-mineral resources in the form of ilmenite minerals or in this case is of beach placer deposit types, will have most likely to be developed economically. The reasons are simply because from the long history of iron sand mining along the south beach of Java especially in South West Java, Titanium minerals (ilmenite and titanomagnetite) are usually accompany of magnetite commodity. Present day, iron sand mines with mostly small scale are still active to produce iron sand concentrates and ilmenite minerals as well.

As part of heavy mineral sands, Titanium minerals are relatively easy to be processed because they are composed of simple mineralogical composition. Moreover, today there are available sophisticated technology for mineral dressing where the promotion of such prosessing techonology isadvertised through website, so easily to access.From the technology information, ilmenite minerals with approximately $10 \%$ of total heavy minerals, for example, is enable to be upgraded to more than five times $\mathrm{TiO}_{2}$ contents, so that can meet market grade which is normally greater than $50 \%$. For this, the resources along the South Java beach, North Sulawesi beach and some of Sumatra placer deposits are possible to have economic significance compared to others in context of total resources, $\mathrm{TiO}_{2}$ contents and mineralogical composition.

In the context of quantity and quality of resources and their deposit types compared to that of processed ones in different countries, the evaluation results of every Titanium resources in Indonesia are summarized in Table 2.

Malaysia that had produced Titanium minerals up to 244,642 tons according to data in 1997 (Joseph, 2000) will become

Table 1. Type of Titanium-Mineral deposits, their economic significance, and their Titanium minerals (Force, 1991)

\begin{tabular}{|c|c|c|c|c|}
\hline Class & Type & Typical Mineralogy & Importance* & Example \\
\hline \multirow{3}{*}{ 1. Metamorphic } & \multirow{3}{*}{$\begin{array}{l}\text { a. Edologite } \\
\text { b. Aluminosilicate } \\
\text { c. Ultramatic contact }\end{array}$} & Rutile & B & \multirow{3}{*}{$\begin{array}{l}\text { Piampaludo, Italy } \\
\text { Evergreen, Colorado } \\
\text { Dinning, Maryland }\end{array}$} \\
\hline & & Rutile & $\mathrm{E}$ & \\
\hline & & Rutile & $E$ & \\
\hline \multirow{4}{*}{ 2. Igneous } & \multirow{4}{*}{$\begin{array}{l}\text { a. Magmatic ilmenite } \\
\text { b. Anorthosite-margin } \\
\text { c. Albitite (kragerite) } \\
\text { d. Alkalic }\end{array}$} & \multirow{4}{*}{$\begin{array}{l}\text { Ilmenite } \\
\text { rutile,ilmenite } \\
\text { Rutile } \\
\text { Perovskite } \\
\text { Nb-rutile, } \\
\text { Nb-brookite }\end{array}$} & A & $\begin{array}{l}\text { Allard lake, Canada; } \\
\text { Roseland, Virginia } \\
\text { (in part) }\end{array}$ \\
\hline & & & C & $\begin{array}{l}\text { Roseland, Virginia } \\
\text { (in part) }\end{array}$ \\
\hline & & & $E$ & Kregem, Norway \\
\hline & & & C & $\begin{array}{l}\text { Powderhom, Colorado; } \\
\text { Magnet Covo, Arkansas }\end{array}$ \\
\hline \multirow{2}{*}{ 3. Hydrothermal } & \multirow{2}{*}{ - } & Pophyry & - & \\
\hline & & Rutile & C & Bingham, Utah \\
\hline \multirow{4}{*}{ 4. Sedimentary } & a. Fluvial & IImenite,rutile & A & Gbangbama, Sierra Leone \\
\hline & b. Glaciolacustrine & Ilmenite & $\mathrm{C}$ & Port leyden \\
\hline & $\begin{array}{l}\text { c.Shoreline (and } \\
\text { coastal eolin) }\end{array}$ & IImenite, & A & $\begin{array}{l}\text { Richards Bay, South Africa; } \\
\text { Stradbroke Island, } \\
\text { Australia; Trail Ridge, } \\
\text { Florida (in part) }\end{array}$ \\
\hline & & $\begin{array}{l}\text { Ilmenite,altered, } \\
\text { IImenite,rutile }\end{array}$ & A & Richards Bay, \\
\hline \multirow{3}{*}{ 5. Weathered } & a. Alcalic parent rock & Anatase & $\mathrm{B}$ & Tapira, Brazil \\
\hline & b.Mafic parent rock & Ilmenite & $\mathrm{D}$ & $\begin{array}{l}\text { Roseland,virginia } \\
\text { (in part) }\end{array}$ \\
\hline & c.Placer parent & $\begin{array}{l}\text { Altered ilmenite, } \\
\text { "leucoxene" }\end{array}$ & $\mathrm{A}$ & $\begin{array}{l}\text { Trail Ridge, Florida } \\
\text { (in part) }\end{array}$ \\
\hline
\end{tabular}


good example for development of BangkaBelitung Titanium mineral resources because they have similarity in deposit characteristics and also geological environments.

The problem faced in development of Titanium commodity in Bangka-Belitung may be more complex in mineralogy aspects because the presence of radioactive minerals in deposits makes difficulty in mineral dressing and refinery process. And also, heavy minerals in Bangka-Belitung is various in mineralogy composition so this should take into account in mineral separation.

Nevertheless, other aspects rather than resources availablity and their mineralogy types such as environment issues may have some complicated problems should be solved on coastal regions.

The lateritic type that associates with bauxite in western part of the country and with nickel in other parts, both have not been exploited for Titan, there is no official data about Titanium production as by product of bauxite and nickel. On the basis of $\mathrm{TiO}_{2}$ contents, lateritic Titanium deposits in this region may have not economic significance if only yielding Titanium commodity as a single product.

\section{CONCLUSION}

Titanium resources in Indonesia are distributed in accordance with Tertiary volcanic rocks for Sumatra-Java and Flores beach placer deposits, with Jura-Triassic granitic and Perm-Carbonaceous metamorphic rocks for Bangka-Belitung and Riau Titanium alluvial deposits, with granitic and ultramafic rocks for Kalimantan and Sulawesi lateritic Titanium deposits. The total resources vary with deposit types where lateritic types tend to be higher in volume but lower in $\mathrm{TiO}_{2}$ contents, while beach placer or alluvial deposits shows moderate in quantity but significant in $\mathrm{TiO}_{2}$ contents.

In summary, on the basis of resources availability, deposit types and the availability of sophisticated processing technologies, beach placer deposits in Sumatera, Java and Sulawesi indicate to have economic significance to be developed today. However, such available data resources are strongly recommended to be upgraded through detail and systematic exploration. Government policies and environment concerns are important aspects for consideration in Titanium commodity development in the country.

Table 2. Summary of Titanium Resources and Reserves in Indonesia

\begin{tabular}{|c|c|c|c|c|c|}
\hline No & Island & $\begin{array}{c}\text { Deposit } \\
\text { types }\end{array}$ & $\begin{array}{c}\text { Resources } \\
\text { (tons) }\end{array}$ & $\begin{array}{c}\text { Reserves } \\
\text { (tons) }\end{array}$ & Remarks \\
\hline \multirow[t]{2}{*}{1} & \multirow[t]{2}{*}{ Sumatera } & Placer & $\begin{array}{c}11,072,6_{2} 0 \\
\mathrm{TiO}_{2} 5,47 \%- \\
25,15 \%\end{array}$ & $(2010)$ & $\begin{array}{c}\text { Possible } \\
\text { Economic } \\
\text { significance for } \\
\text { Titan Commodity } \\
\text { Development }\end{array}$ \\
\hline & & Laterite & $\begin{array}{c}107,800,859 \\
\mathrm{TiO}_{2} 0,5 \%- \\
15 \%\end{array}$ & - & 5ovorupmom \\
\hline 2 & Java & Placer & $\begin{array}{c}27,469,600 \\
\mathrm{TiO}_{2} 9,12 \%- \\
23,17 \%\end{array}$ & $\begin{array}{c}21,922,229 \\
\mathrm{TiO}_{2} 8,92 \%- \\
9,629 \%\end{array}$ & $\begin{array}{c}\text { Possible } \\
\text { Economic } \\
\text { significance for } \\
\text { Titan Commodity } \\
\text { Development }\end{array}$ \\
\hline 3 & Kalimantan & Laterite & $\begin{array}{c}596,497,700 \\
\mathrm{TiO}_{2} 0,5 \%- \\
15 \%\end{array}$ & - & 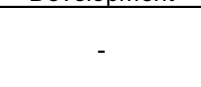 \\
\hline 4 & Flores & Placer & $\begin{array}{c}175,000 \\
\mathrm{TiO}_{2} 7,15 \%\end{array}$ & - & - \\
\hline \multirow[t]{2}{*}{5} & \multirow[t]{2}{*}{ Sulawesi } & Placer & $\begin{array}{c}32,597,590 \\
\mathrm{TiO}_{2} 0,9 \%- \\
9,85 \%\end{array}$ & - & $\begin{array}{c}\text { Possible } \\
\text { Economic } \\
\text { significance for } \\
\text { Titan Commodity } \\
\text { Development }\end{array}$ \\
\hline & & Laterite & $\begin{array}{l}37,000,000 \\
\mathrm{TiO}_{2} 0,15 \%\end{array}$ & - & - \\
\hline \multicolumn{3}{|c|}{ Total } & $\begin{array}{c}812,613,169 \\
\mathrm{TiO}_{2} 0,15 \%- \\
25,15 \%\end{array}$ & $\begin{array}{c}21,922,229 \\
\mathrm{TiO}_{2} 8,92 \%- \\
9,629 \%\end{array}$ & \\
\hline
\end{tabular}




\section{MAKALAH ILMIAH}

\section{REFERENCES}

Anonim. 2005: Iron Sand Exploration Technical Guidelines, Directorate of Mineral Resources Inventory. Unpublished.

Anomim. 2013. Ilmenite data Bangka Belitung and Riau Islands, PT. Timah Tbk. Unpublished.

Anonim., 2011, Iron Sand prospecting in West Lampung, Lampung Province. Centre for Geological Resources. Unpublished.

Anonim, 2012: Database Mineral Logam, Centre for Geological Resources. Unpublished.

Ansori, Chusni. 2011 : Iron Sand Mineralogy distribution on the South Coast track KebumenKutoarjo, Geological Resources newsletter. Vol.6 No.2 August 2011.

Aliamin Husin, 1971. Titano Iron Deposit at The Southern Coast of Kulon Progo, Yogyakarta, Directorate of Geology.

A. Fuad, A. Tanjung, 1996 : Titan Dioxide Extraction of Iron Sand D.I Yogyakarta.

A. Yaghubpur, Y. Rahimanuri and S. Alipaur, 2007 : Mineralogy, Geochemistry, of Titanium Rick Rocks of Yara Agaj, Urmia, North west Iran, University of Teheran.

Force, E R, 1991: Geology of Titanium- Mineral Deposit. U.S. Geological Survey Special Paper, 259pp.

Gambagi, J, 2000: Titanium, US Geological Survey Minerals Yearbook 2000.

Mutalim, Tri Murti dan Toni Suryadi, 1992 : Assessment Preparation of $\mathrm{TiO}_{2}$ Pigment Iron Sand Ilmenite Jampang Kulon area Sukabumi West Java.

Van Bemmelen, R.W., 1949: The Geology of Indonesia Vol II Economic Geology.

Subandoro, 1972. Official Travel Report of Iron Sand Central Java. Directorate of Geology .

Sutedjo, Sujitno, 1997: Primary Tin in Indonesia (Geology and the Explration). PT. Tambang Timah (Persero).

Walmen Simanjuntak, 1996: Trial Titan Dioxide Extraction of Iron Sand D.I Yogyakarta. PPTM. http://www.asianmetal.com/news/getProducsNewsEn.am?productThreelD=51. 